\title{
An update on head and neck squamous cell carcinoma in respect to classification and systemic therapy. Extended review
}

\author{
A. Mudunov' ${ }^{1}$, A. Ahundov' ${ }^{1}$, M. Bolotin ${ }^{1}$, T. Braunschweig ${ }^{2}$ \\ ${ }^{1}$ N.N. Blokhin National Medical Research Center of Oncology, Ministry of Health of Russia; \\ 23 Kashirskoe Road, Moscow 115478, Russia \\ ${ }_{2}^{2}$ Institut für Pathologie, Universitätsklinikum Aachen; 30 Pauwelsstraße, D-52074 Aachen, Deutschland \\ Contact: Michael Bolotin bolotin1980@mail.ru
}

Head and neck squamous cell carcinoma (HNSCC) is among the 10 most common cancers and demonstrates high mortality rates. Well known for its relation to smoking and alcohol consumption, in within the past 10 years a high number of cases, especially of the oropharynx could be shown to be based on an infection of human papilloma virus, high risk subtypes, mostly type 16 and 18. Often it is connected to younger age at onset, better outcome and better response to radiochemotherapy.

Next to well established radiochemotherapy schemes, including targeted therapy as cetuximab, in the recent 2 years a complete new therapeutic approach manifested, called checkpoint inhibition. The drugs of this class block a binding of a membranous ligand to a surface receptor on T-cells. Without blocking, this binding is physiological in antigen-presenting cells or many other normal tissue cells (e.g. heart muscle, trophoblast) inhibiting activation of the cytotoxic T-cells. Research revealed an identical way of tumor cells escaping cell death caused by patient's own immune system. By blocking this inhibition, in several carcinoma entities, a very effective disease control was achieved. So far, 2 pairs of binding are approved for treatment: CD80-CTLA4 and PD1-PDL1. In CD80-CTLA4, it is an inhibitor to CTLA4 (e. g. Ipilimumab), in PD1-PDL1, for both, the ligand an receptor are several inhibitors on the market (e. g. Nivolumab, Pembrolizumab, Atezolizumab, Durvalumab). So far, there could not be found a highly predictive marker for the grade of efficiency of these inhibitors. Next to very recent and complex markers, tumor mutational burden, the immunohistochemical staining for the ligand, PD-L1 could be established in a few number of carcinoma, incuding adenocarcinoma of the lung. Next to different ways of interpretation of the staining, also different staining procedures used in the trials are hindering an easy establishment of this marker in pathology laboratories. The staining procedures used in trials are not comparable with common immunohistochemistry due to very high costs of reagents (test-kits sold by the involved companies, so called companion diagnostic). To overcome these drawbacks, different studies were performed comparing the different antibody clones of immunohistochemical stains used in the official trials and antibodies of other companies. These harmonization studies brought to light that most antibodies stain equally, even the antibodies available from other companies thus making this stain more effordable and possible for introduction in the marker-portfolio of labs of pathology.

In HNSCC there is a better response to checkpoint inhibitors in cases of high PD-L1 expression, but also in negative cases, an effect could be seen. The actual approval are exclusively for patients in second line without PD-L1 testing. Upcoming approvals for first line treatment by checkpoint inhibitors are likely to include immunohistochemical testing for PD-L1.

Key words: head and neck squamous cell carcinoma, radiochemotherapy, checkpoint inhibition, Ipilimumab, Nivolumab, Pembrolizumab, Atezolizumab, Durvalumab

For citation: Mudunov A., Ahundov A., Bolotin M., Braunschweig T. An update on head and neck squamous cell carcinoma in respect to classification and systemic therapy. Extended review. Opukholi golovy i shei = Head and Neck Tumors 2018;8(1):48-55.

DOI: $10.17650 / 2222-1468-2018-8-1-48-55$

Новые результаты исследования плоскоклеточного рака головы и шеи в отношении классификации и системной терапии. Расширенный обзор

\author{
А. Мудунов ${ }^{1}$, А. Ахундов ${ }^{1}$, М. Болотин ${ }^{1}$, Т. Брауншвейг ${ }^{2}$ \\ ${ }^{1}$ ФГБУ «Национальный медицинский исследовательский центр онкологии им. Н.Н. Блохина» Минздрава России; \\ Россия, 115478 Москва, Каширское шоссе, 24 \\ ${ }^{2}$ Институт патологии Университетской клиники г. Аахен; Германия, D-52074 Аахен, Пауэльштрассе, 30
}

Плоскоклеточный рак головы и шеи (ПРГШ) входит в десятку наиболее часто встречающихся форм и характеризуется высокими показателями летальности. Хорошо известна его связь с курением и употреблением алкоголя. Несмотря на это в последние время все чаще диагностируется ПРГШ, особенно ротоглотки, ассоциированный с вирусом папилломы человека подтипов высокого риска, преимущественно 16 и 18. Часто его развитие коррелирует с молодым возрастом, лучшим ответом на консервативную химиолучевую терапию и лучшим прогнозом. 
Наряду с общепринятыми схемами конкурентного химиолучевого лечения, включая таргетную терапию цетуксимабом, в последние 2 года появился совершенно новый класс препаратов - противораковые моноклональные антитела. Препараты этого класса блокируют связывание мембранного лиганда с поверхностным рецептором Т-клеток. В норме эта связь является физиологической для антигенпрезентирующих клеток и множества других нормальных клеток (например, кардиомиоцитов, трофобластов), ингибирующих активацию цитотоксических Т-клеток. Исследования показали, что нечто похожее происходит с опухолевыми клетками, избегающими клеточной смерти, которую вызывает функционирование собственной иммунной системы пациента. Данные препараты уже показали свою эффективность при некоторых формах рака.

В настоящее время только 2 комбинации одобрены для терапии: CD80-CTLA4 и PD1-PDL1. Комбинация CD80-CTLA4 представлена ингибитором CTLA4 (например, ипилимумаб), комбинация PD1-PDL1 представлена на фармацевтическом рынке ингибиторами как для PD1, так и PDL1 (ниволумаб, пембролизумаб, атезолизумаб, дурвалумаб). На данный момент невозможно выделить высокоточный прогностический критерий оценки эффективности этих препаратов. Следом за недавно выявленными комплексными критериями (мутационная нагрузка опухоли) может быть использовано иммуногистохимическое окрашивание лиганда PD-L1 в нескольких видах карцином, включая аденокарциному легкого. Наряду с различными способами интерпретации окрашивания, различные процедуры окрашивания, используемые в исследованиях, также препятствуют широкому внедрению этого маркера в работу лабораторий. Процедуры окрашивания, используемые в исследованиях, несопоставимы с общепринятой практикой проведения иммуногистохимического анализа из-за высоких затрат на реагенты (тест-наборы для так называемой сопутствующей диагностики). Для преодоления этих препятствий были проведены исследования, сравнивающие различные клоны антител для иммуногистохимического окрашивания, используемые в официальных испытаниях, и антитела других компаний. Такие сравнительные исследования установили, что большинство антител окрашиваются одинаково, в том числе антитела, предлагаемые другими компаниями, что делает проведение окрашивания более легким и позволяет ввести их в арсенал лабораторий.

При ПРГШ наблюдается лучший ответ на терапию у пациентов с высоким уровнем экспрессии PD-L1, однако отсутствие экспрессии далеко не всегда означает отсутствие клинического ответа на терапию. В настоящее время очевидно, что данные препараты являются препаратами терапии 2-й линии у пациентов с неизвестным статусом PD1/PDL1. Для решения о применении данных препаратов как терапии 1-й линии необходимы большие рандомизированные исследования с обязательной оценкой статуса экспрессии.

Ключевые слова: плоскоклеточный рак головы и шеи, радио- и химиотерапия, ингибирование контрольных точек, ипилимумаб, ниволумаб, пембролизумаб, атезолизумаб, дурвалумаб

Для цитирования: Мудунов А., Ахундов А., Болотин М., Брауншвейг Т. Новые результаты исследования плоскоклеточного рака головы и шеи в отношении классификации и системной терапии. Расширенный обзор. Опухоли головы и шеи 2018;8(1):48-55.

\section{Introduction}

Squamous cell carcinoma of the head and neck derive from different sides, including oral cavity, oropharynx, nasopharynx, hypopharynx and larynx. This group of carcinomas, head and neck squamous cell carcinoma (HNSCC), show a wide range of incidences among the world, being more prevalent in some parts of South America and Asia, due to consumption of alcohol, bethel quid or cigarette smoking and, rising in recent years, infection by high-risk human papilloma virus (HPV) types, mostly HPV type 16 and 18 [1, 2]. The way of interacting of HPV high risk types and the host genome is based on expression of viral gene products, E6 and E7, leading to an uncontrolled cell proliferation by inactivation of p53 and $\mathrm{rb}$ (retinoblastoma-gene product) [3].

HNSCCs are linked to high morbidity and mortality rates (up to $50 \%$ ) due to the spectrum of affected patients and high recurrence rates. While the incidence of HPV related HNSCC rise, non-HPV related HNSCC are decreasing $[4,5]$. In general, the age-standardization frequency of head and neck cancer worldwide is 8.1 per 100,000 . In 2008, 550,319 new head and neck cancer cases were diagnosed worldwide, while in 2012 that number grew to 599,637 with
324,834 related deaths [6]. Classical site for HPV related squamous cell carcinoma (SCC) is the oropharynx, as palatinal or lingual tonsils, but lately, the number of HPV positively tested cases of sinonasal SCC and laryngeal SCC are rising or diagnosed in a significant number as well [7, 8]. The 5-year survival rate is more favorable in HPV positive cases than in HPV negative cases, due to less recurrence rates and better response to radiochemotherapy $[8,9]$. One explanation of better prognosis in HPV positive SCC is the intrinsic immune response to the tumor, reflected by infiltrating T-cells [10].

The classical surrogate marker for HPV positive cases is the immunohistochemical stain for $\mathrm{p} 16$ or the product of the gene $C D K N 2 A$ [11]. In oropharyngeal squamous cell carcinoma, in some extend depending on the country or continent, p16 marks HPV high-risk positive cases up to $100 \%$, but down to $80 \%[12,13]$, due to the prevalence of infections by subtype HPV type 16. Other types, including type 18 does not seem to be related to stable p16 expression. By publications using meta-analysis, it could be shown that p16 status is not a complete independent marker for outcome, but the combination of HPV testing by DNA extraction and PCR based detection: HPV+/p16+ cases 
had the best prognosis, HPV-/p16+ intermediate and $\mathrm{HPV}+/ \mathrm{p} 16$ - and HPV-/p16- the worst [9].

By screening HNSCC for HPV relation, p16 is the recommended marker, especially in oropharyngeal SCCs with a cut off value of $70 \%$ stained tumor area [11]. There are no recommendations concerning the used antibody clone. As it is well established as being strongly expressed in almost $100 \%$ of SCC of the cervix uteri [14], it is up to the pathological laboratory to establish a specifically staining antibody using for example SCC of cervical SCC as a positive control.

\section{Diagnosis}

Diagnostic approaches include always a biopsy taken of the tumor side by endoscopy. Histologically, a squamous cell carcinoma can be challenging in case of low differentiation or basaloid differentiation and depending on the surrounding inflammatory infiltration. HPV positive squamous cell carcinomas show generally a distinct pattern of basaloid cell types and no typical squamous stratification or keratinized differentiated parts [15]. As shown in figure 1, a typical keratinizing squamous cell carcinoma of the tongue, p16 negative, is shown in $1 \mathrm{~A}$ and $1 \mathrm{~B}$. In comparison, a basaloid squamous cell carcinoma origin in the tonsil, p16 positive, is shown in $1 \mathrm{C}$ and $1 \mathrm{D}$.

\section{New approaches for therapy}

Within the guidelines in western countries (for example NCCN, USA), as for most carcinomas, complete surgical
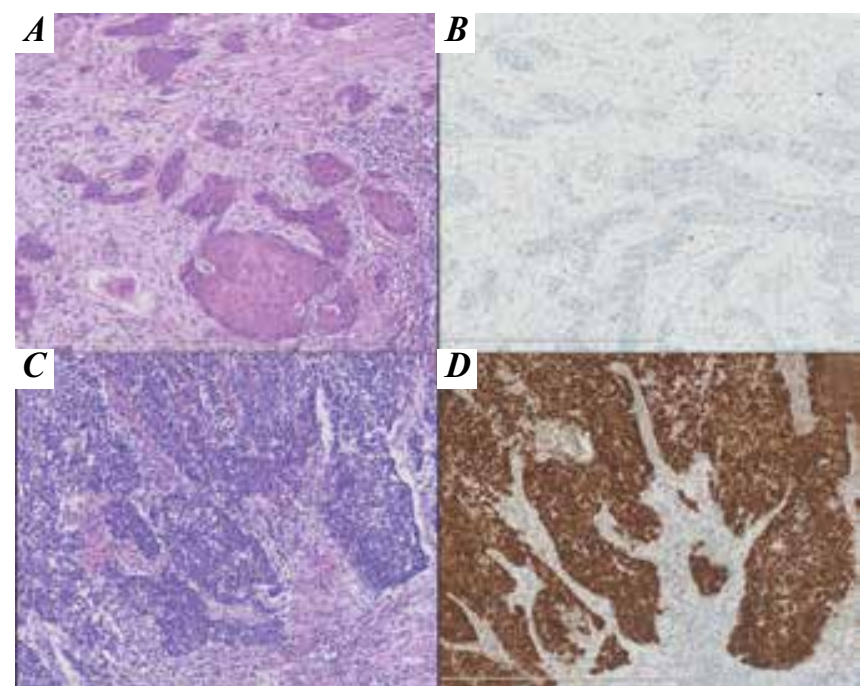

Fig. 1. Two cases of squamous cell carcinoma (SCC) of the head and neck: $A$ and $B-a$ SCC of the tongue, showing infiltrates of a keratinizing carcinoma with partly differentiated epithelial organization (A) and being negative for p16 (B); $C$ and D - a SCC of the tonsil, classical side for oropharyngeal carcinoma, positive for $p 16$ (in D) and showing the characteristic basaloid differentiation of tumor cells without keratinization or differentiated epithelium (in C). All histological photographs at $\times 200$, using Hamamatsu Scanner, HT2.0 (Hamamatsu, Herrsching, Germany); immunohistochemical stain by monoclonal mouse anti-p16 by Merck (Merck, Darmstadt, Germany) using DAKO/Agilent Autostainer and Flex Kit (Agilent, Waldbronn, Germany) resection comes with best prognosis. In unresectable cases or unresectable recurrance, systemic therapy as a combinated chemoradiotherapy, using classical chemotherapeutics, for example cisplatin and radiation or targeted therapeutics, as cetuximab and radiation [16]. In non-naso-pharyngeal SCC in cases of recurrence after platinum containing therapy or progression under platinum containing therapy, a relatively new therapeutic agent, Pembrolizumab (MSD), was approved by the FDA and EMA [16]. Pembrolizumab (MSD) counts to the new group of so called checkpoint-inhibitors, representing a class of therapeutics interacting with the communication of tumor cells and cytotoxic T-cells [17]. In general, checkpoint inhibitors are blocking the ligand binding of the tumor cell on the receptor on the cytotoxic T-cell in order to activate the T-cells to attack tumor cells. In many different tumor entities, trials had been executed with different types of checkpoint inhibitors, mainly blocking interactions of PD-1/PD-L1 and CD80/CTLA4. By several authors and speakers, checkpoint inhibitors are called "the fourth modality" next to the well established treatment options: surgery, radiation and chemotherapy [18].

One of the first tumor entities in which checkpoint inhibitors were tested in trials was the malignant melanoma of the skin. Here, CTLA4 inhibitor Ipilimumab (BMS) didn't reveal high response rates (5-15\%), but still better than prior regimes. With PD-1 inhibitors like Nivolumab, up to 30-45\% stable response rates were achievable [18].

For HNSCC, in case of CTLA4 several inhibitors are under investigation and mostly in combined therapies with another drug, none of the studies revealed a predicting biomarker as a immunohistochemical staining [19]. In case of PD-1 and PD-L1 inhibitors, many different drugs were developed (a selection is listed below) and set up in numerous trials from phase I to phase III. From beginning on, immunohistochemical expression of PD-L1 in tumor cells or so called "immune cells" in inflammatory infiltrates within the tumor (mainly histiocytic cell types) were chosen as a major depending variable in the analysis of efficacy of the drug [19]. The number of PD-1 positive lymphocytes within or adjacent to the tumor was discussed in the beginning but not followed [10]. In the last years, an additional predictive biomarker for the positive response to checkpoint inhibitors revealed the tumor mutational burden, TMB. The TMB had been tested in HNSCC and showed to be much higher in non-HPV related carcinomas [20]. In theory, TMB high tumors should be related to a high internal immune response due to a higher number of neo antigens on the cell surface. Other factors are discussed to play a role as microbiome or inflammatory signatures [21].

As for Pembrolizumab (MSD), equally for Nivolumab (BMS), it inhibits the receptor on the T-cell (see figure 2). Other inhibiting drugs are blocking the ligand as there are Atezolizumab (Roche), Durvalumab (AstraZeneca) and Avelumab (Merck). With these 5 drugs, the interaction 


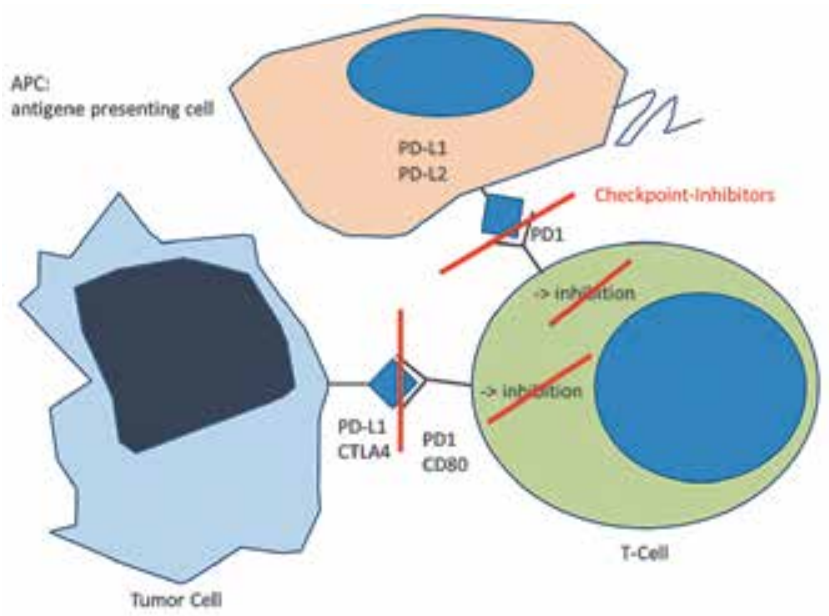

Fig. 2. Cell interaction of checkpoint ligand/receptors: between antigenpresenting cells $(A P C)$ and $T$-cells via $P D-1$ and $P D-L 1$ and $P D-1$ and $P D$ L2 in order to inhibit cytotoxic effects on APC. Tumor cells escape cytotoxic effects by inhibiting T-cells the same way, here demonstrated CD80 and CTLA4 and $P D-1$ and PD-L1. By blocking either one of them, the immune system can be reactivated by the 'inhibition of the inhibition', calling these drugs checkpoint inhibitors

of the receptor programmed-cell death-1 (PD-1) and programmed cell death-ligand-1 (PD-L1) is meant to be suppressed [22]. As depicted in figure 2, PD-L1 is not only expressed on tumor cells, but also on antigen-presenting cells, as dendritic cells. This kind of treatment is not meant to be curative but to control the disease in order to reduce tumor burden or to receive stable disease. Side-effects of these drugs are in general less severe, as inflammation of lungs, colon and liver, but mostly well treatable [22].

So far, of the five mentioned actual drugs in use or in close future use, are primarily tested in second line and after successful first line application. Nivolumab and Pembrolizumab had been under investigation in Phase III trials in HNSCC: Nivolumab in CheckMate studies (No 141) and Pembrolizumab in Keynote studies (No 012, 048, 055). Atezolizumab and Durvalumab had also been investigated on HNSCC in phase I and II studies [23, 24]. In the trial of Atezolizumab, there could not be shown any connection of the response to HPV status (p16 positivity) or PD-L1 immunohistochemical expression. In Durvalumab, only tumors with a PD-L1 expression of at least $25 \%$ of tumor cells were included. Here p16, resp. HPV positive patients showed a better outcome [24].

In actual studies, the single drug as second line or first line is no longer much under investigation, but combination with other drugs/therapies or an established treatment followed by a checkpoint inhibitor (see table 2).

In the diverse trials of the four main drugs, different staining protocols and data assessment for the immunohistochemistry of PD-L1 expression were carried out (see table 1). Staining was always counted positive as a membranous staining, independently from the amount of staining and ht stained portion of the membrane. The staining procedures were different in means of used staining machines and staining reagents, playing a minor role. The main role comes down to the used primary antibodies. As shown in figure 3, PD-L1 staining is mostly seen and counted on the membrane. Cytoplasmic stain is generally not mentioned in the trials. As demonstrated in figure 4 and revealed in harmonization studies of different groups, the antibody clones: $28.8,22 \mathrm{C} 3$ and SP263 are staining more equally with differences in intensity. The clone SP142 stained significantly less tumor cells but highlight more immune cells $[25,26]$.

Even if many trials resulted in an approval of one of the drugs in different entities without necessary immunohistochemical testing for PD-L1, it still remains a useful biomarker. In many entities, higher response rates or progression free survival time could be described in tumors showing high expression of PD-L1 in tumor cells. But, as in approved treatments without mandatory testing, also low-expressing or not expressing tumors revealed good enough response rates. In special situations, an immunohistological testing is useful to determine if the treatment with checkpoint inhibitors might work better: malignant melanoma and single treatment with Nivolumab due to higher side effects of Ipilimumab in combination therapy; or in patients who had to pay for the drug themselves.

In general, there was no correlation mentioned concerning PD-L1 status and p16/HPV [19]. But HPV positiv-

Table 1. Main four checkpoint-inhibitors of PD-1 and PD-L1 and their detection systems/methods used in trials

\begin{tabular}{|l|c|c|c|c|}
\hline \multicolumn{1}{|c|}{ Characteristic } & Nivolumab (BMS) & Pembrolizumab (BMS) & Atezolizumab (Roche) & $\begin{array}{c}\text { Durvalumab } \\
\text { (AstraZeneca) }\end{array}$ \\
\hline Antibody clone & 28.8 & $22 \mathrm{C} 3$ & SP142 & SP263 \\
\hline Company & Agilent/DAKO & Agilent/DAKO & Ventana/Roche & Ventana/Roche \\
\hline Compartment & TC & TC and TC/IC: CPS & TC and TC & TC \\
\hline Cut offs, in $\%$ & $\geq 1, \geq 5, \geq 10$ & $\geq 1, \geq 50$ & $\begin{array}{r}\text { TC: }: \geq 1, \geq 10, \geq 50 \\
\text { IC: } \geq 1, \geq 5, \geq 10\end{array}$ \\
\hline
\end{tabular}


Table 2. Actual studies on combination of checkpoint inhibitors and other treatments

\begin{tabular}{|c|c|c|c|c|}
\hline Group & Drug & Short description & Name & Ref \\
\hline \multirow{3}{*}{ anti-CTLA4 } & \multirow{2}{*}{$\begin{array}{l}\text { Ipilimumab } \\
\text { (BMS) }\end{array}$} & $\begin{array}{l}\text { Combination of Cetuximab, Radiation and } \\
\text { Ipilimumab in first line PULA HNSCC }\end{array}$ & - & [27] \\
\hline & & Ipilimumab plus Nivolumab & $\begin{array}{l}\text { CheckMate } \\
\text { 651\&714 }\end{array}$ & {$[28,29]$} \\
\hline & $\begin{array}{l}\text { Tremelimumab } \\
\text { (AstraZeneca) }\end{array}$ & Tremelimumab plus Durvalumab & Kestrel & {$[30]$} \\
\hline \multirow{4}{*}{ anti-PD-1 } & Pembrolizumab & $\begin{array}{c}\text { Combination with Chemo and Radiation and } \\
\text { Pembrolizumab }\end{array}$ & - & {$[31]$} \\
\hline & \multirow{3}{*}{ Nivolumab } & Ipilimumab plus Nivolumab & $\begin{array}{l}\text { CheckMate } \\
651 \& 714\end{array}$ & {$[28,29]$} \\
\hline & & Nivolumab plus Chemotherapy & $\begin{array}{l}\text { Checkmate } \\
227\end{array}$ & {$[32]$} \\
\hline & & $\begin{array}{l}\text { Induction of Chemo plus Nivolumab followed } \\
\text { by surgery (similar to neoadjuvant) }\end{array}$ & Optima2 & {$[33]$} \\
\hline anti-PD-L1 & Durvalumab & Durvalumab plus Tremelimumab & Kestrel & [30] \\
\hline
\end{tabular}

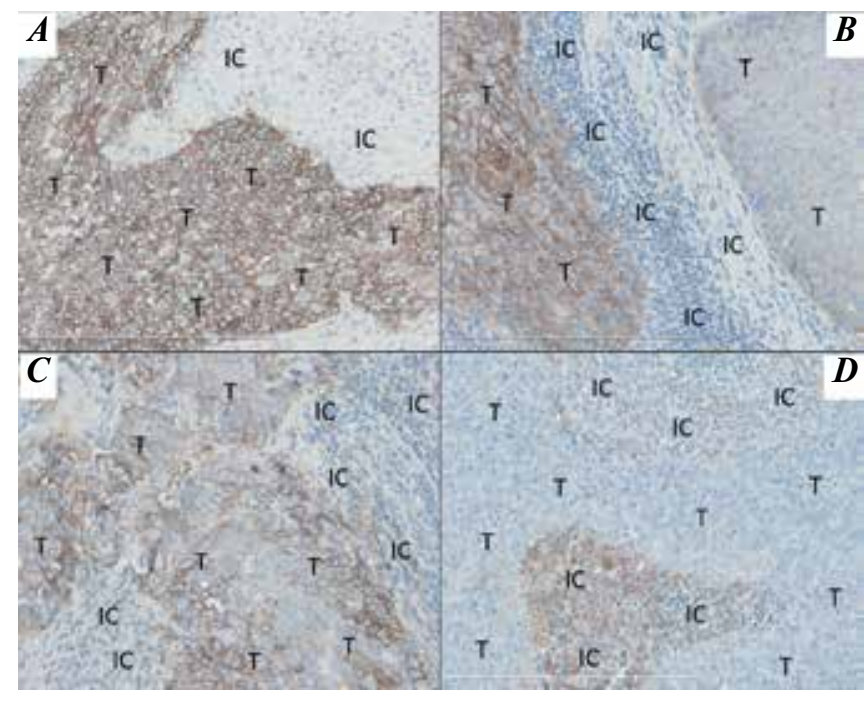

Fig. 3. Different main types of staining of PD-L1 in HNSCC ( $T$ - tumor cells, IC - "immune cells"): $A$ - homogenous, strong membranous stain of exclusively tumor cells $(T) ; B-a$ case of heterogeneous stain within the tumor infiltrates (T) (left strong stain, right almost no stain); $C$ - a case of slightly heterogeneous stain within the tumor $(T)$ but also positivity of tumor adjacent inflammatory cells (IC), so called "immune cells" mainly stained are histiocytic cells as macrophages; D - exclusively stained tumor adjacent "immune cells" (IC) - tumor cells are negative (T). All photographs at 200, immunohistochemistry by DAKO/Agilent rabbit monoclonal antibody 22C3, stained with Agilent/DAKO autostainer and Flex Kit (Agilent, Waldbronn, Germany)

ity was used for stratification of patients in respect to risk groups for selection of patients for different trials.

The only actual need for an immunohistochemical grading of $\mathrm{PD}-\mathrm{L} 1$ is in the application of Pembrolizumab in first or second line in NSCLC (at least $1 \%$ in second line and at least $50 \%$ in first line treatment). In the close future,

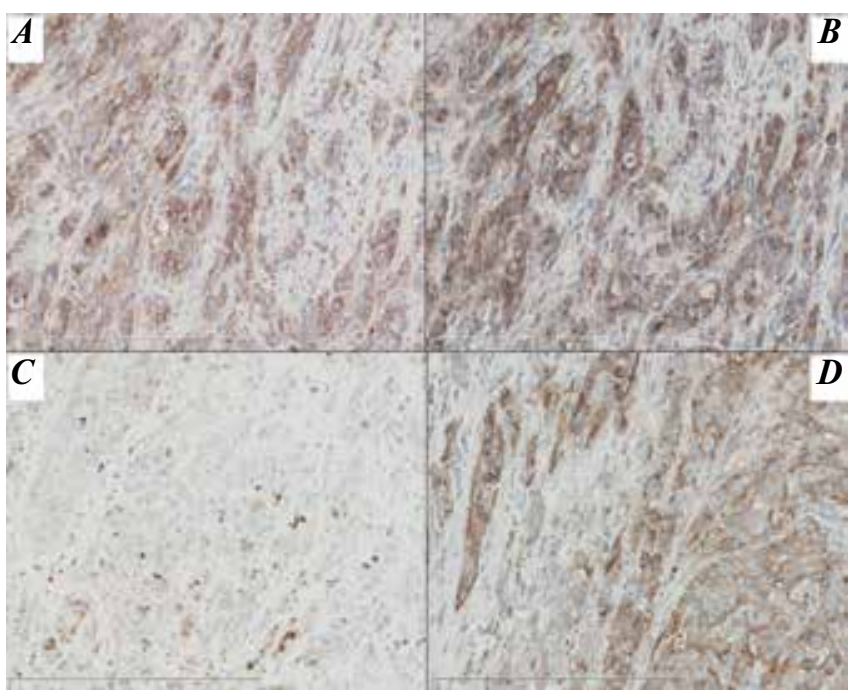

Fig. 4. As demonstrated also in different studies, the three stains in A (clone 28.8), B (clone 22C3) and D (clone SP263) stain differently, but the same amount of tumor cells (staining counted irrespectively the strength). The stain in $C$ does stain much less - in studies significantly less - tumor cells, but highlights positive immune cells with a dot-like staining pattern. The four different types of antibodies/test kits used in the trials: A - Agilent/DAKO monoclonal mouse, 28.8; B - Agilent/DAKO monoclonal rabbit, 22C3; C Ventana/Roche monoclonal rabbit, SP142; D - Ventana/Roche monoclonal rabbit, SP263 (Ventana, Tucson, AZ, USA). All stains performed with Agilent) DAKO Autostainer and Flex system (Agilent, Waldbronn, Germany)

Pembrolizumab might be approved for first line treatment in HNSCC in higher expressing tumors of a so called "combined-positive-score (CPS)" for PD-L1. The CPS counts positive staining of tumor cells and adjacent inflammatory cells divided by vital tumor cells and need to be greater than 1 . 
Table 3. Antibodies to test for PD-L1 immunohistochemistry (adjusted from S.Kintsler et al. [34])

\begin{tabular}{|l|c|c|c|c|c|c|c|c|c|c|c|c|}
\hline Characteristic & Agilent & Agilent & Ventana & Ventana & $\begin{array}{c}\text { Cell } \\
\text { Signalling }\end{array}$ & Abcam & Zytomed & Quartett \\
\hline Type & mMo & mRab & mRab & mRab & mRab & mMo & mRab & mRab \\
\hline Clone & 28.8 & $22 \mathrm{C} 3$ & SP142 & SP263 & E1L3N & 28.8 & Callo & QR1 \\
\hline $\begin{array}{l}\text { Efficacy } \\
\text { concordant }\end{array}$ & + & + & - & + & + & + & + & + \\
\hline
\end{tabular}

With these special scoring systems and the need of accuracy, next to the different assays used, there was a big need for pathologists to simplify this field and to build up a common base. Harmonization studies of different working groups, the antibody clones: $28.8,22 \mathrm{C} 3$ and SP263 are staining more equally with differences in intensity. The clone SP142 stained significantly less tumor cells but highlight more immune cells $[25,26]$ (see figure 3 ). Next, cut-off values of $1 \%$ are extremely uneasy to read in histological section with a high proportion of tumor tissue. Therefore, Agilent/Dako and MSD organized training work-shops for pathologists.

Due to high costs for the testing kits for the described antibodies (e. g. reagents only DAKO/Agilent: $\sim 3150 € / 50$ tests), also other commercially available antibodies developed for research use were tested. Here, a significant number of well working antibodies could be found [25] and (table 3). Thus, several alternative antibodies are available with much less costs for the pathologist and patient.

\section{Conclusion}

Squamous cell carcinomas of the head and neck are since recent years a field of plasticity and new approaches: after research discovered and established the connection of HPV infection and a subpopulation of HNSCC, the upcoming drug group of checkpoint inhibitors is about to revolutionize the field of treatment which was dominated for decades by radiochemotherapy.

\section{Л И}

1. Aldalwg M.A.H., Brestovac B. Human Papillomavirus Associated Cancers of the Head and Neck: An Australian Perspective. Head Neck Pathol 2017;11(3):377-84

2. Marur S., D'Souza G., Westra W.H., Forastiere A.A. HPV-associated head and neck cancer: a virus-related cancer epidemic. Lancet Oncol 2010;11(8):781-9. DOI: 10.1016/S1470-2045(10)70017-6.

3. Брауншвейг Т., Левандровски А., Смеетс Д., Болотин М.В. Плоскоклеточный рак головы и шеи: новые перспективы лечения? Опухоли головы и шеи 2013;(3):4-10. [Braunschweig T., Lewandrowski A., Smeets D., Bolotin M.V. Squamous cell carcinoma of the head and neck: new avenues of treatment? Opukholi golovy i shei $=$ Head and Neck Tumors 2013;(3):4-10. (In Russ.)] DOI: 10.17650/2222-1468-2013-0-3-4-10.

4. Forman D., de Martel C., Lacey C.J. et al. Global burden of human papillomavirus and related diseases. Vaccine 2012;30(5): F12-23. DOI: 10.1016/j.vaccine.2012.07.055.

5. Hammarstedt L., Lindquist D., Dahlstrand H. et al. Human papillomavirus as a risk factor for the increase in incidence of tonsillar cancer. Int J Cancer 2006;119(11): 2620-3. DOI: 10.1002/ijc.22177.
6. Ferlay J., Soerjomataram I., Dikshit R. et al. Cancer incidence and mortality worldwide: sources, methods and major patterns in GLOBOCAN 2012. Int J Cancer 2015; 136(5):E359-86. DOI: 10.1002/ijc.29210.

7. Bishop J.A., Guo T.W., Smith D.F. et al. Human papillomavirus-related carcinomas of the sinonasal tract. Am J Surg Pathol 2013;37(2):185-92. DOI: 10.1097/ PAS.0b013e3182698673.

8. Shaughnessy J.N., Farghaly H., Wilson L. et al. HPV: a factor in organ preservation for locally advanced larynx and hypopharynx cancer? Am J Otolaryngol 2014;35(1):19-24. DOI: 10.1016/j.amjoto. 2013.08.006.

9. Coordes A., Lenz K., Qian X. et al. Metaanalysis of survival in patients with HNSCC discriminates risk depending on combined HPV and p16 status. Eur Arch Otorhinolaryngol 2016;273(8):2157-69. DOI: $10.1007 / \mathrm{s} 00405-015-3728-0$.

10. Badoual C., Hans S., Merillon N. et al. PD-1-expressing tumor-infiltrating $\mathrm{T}$ cells are a favorable prognostic biomarker in HPV-associated head and neck cancer. Cancer Res 2013;73(1):128-38. DOI: 10.1158/0008-5472.CAN-12-2606.

11. Lewis J.S. Jr., Beadle B., Bishop J.A. et al. Human papillomavirus testing in head and neck carcinomas: Guideline from the College of American Pathologists. Arch Pathol Lab Med 2017; Dec 18. DOI: 10.5858/ arpa.2017-0286-CP.

12. Ndiaye C., Mena M., Alemany L. et al. HPV DNA, E6/E7 mRNA, and p16INK4a detection in head and neck cancers: a systematic review and meta-analysis. Lancet Oncol 2014;15(12):1319-31. DOI: 10.1016/S1470-2045(14)70471-1.

13. Ang K.K., Harris J., Wheeler R. et al. Human papillomavirus and survival of patients with oropharyngeal cancer. N Engl J Med 2010;363(1):24-35. DOI: 10.1056/ NEJMoa0912217.

14. Carozzi F., Gillio-Tos A., Confortini M. et al. Risk of high-grade cervical intraepithelial neoplasia during follow-up in HPVpositive women according to baseline p16INK4A results: a prospective analysis of a nested substudy of the NTCC randomised controlled trial. Lancet Oncol 2013;14(2):168-76. DOI: 10.1016/S14702045(12)70529-6.

15. Muller S., Khuri F.R., Konoet S.A. et al. $\mathrm{HPV}$ positive squamous cell carcinoma of the oropharynx. Are we observing an unusual pattern of metastases? Head Neck Pathol 2012;6(3):336-44. DOI: $10.1007 / \mathrm{s} 12105-012-0355-6$. 
16. Adelstein D., Gillison M.L., Pfister D.G. et al. NCCN Guidelines Insights: Head and Neck Cancers, Version 2.2017. J Natl Compr Canc Netw 2017;15(6):761-70. DOI: 10.6004/jnccn.2017.0101.

17. Haddad R., Seiwert T., Pfister D.G. et al. Pembrolizumab after progression on platinum and cetuximab in head and neck squamous cell carcinoma (HNSCC): results from KEYNOTE-055. Ann Oncol 2016;27(6).

18. Barth C. Immunotherapy for Head and Neck Cancer: The Fourth Modality Has Arrived. Available at: http://www.ascopost. com/issues/march-10-2017/immunotherapy-for-head-and-neck-cancer-thefourth-modality-has-arrived/

19. Economopoulou P., Perisanidis C., Giotakis E.I., Psyrri A. The emerging role of immunotherapy in head and neck squamous cell carcinoma (HNSCC): anti-tumor immunity and clinical applications. Ann Transl Med 2016;4(9):173. DOI: $10.21037 / \mathrm{atm} .2016 .03 .34$.

20. Chung C.H., Frampton G.M., Chalmers Z.R. et al. Genomic profiling of squamous malignancies across anatomic sites. J Clin Oncol 2017;35(15):11512. DOI: 10.1200/ JCO.2017.35.15_suppl.11512.

21. Blank C.U., Haanen J.B., Ribas A., Schumacher T.N. Cancer immunology. The "cancer immunogram". Science 2016;352(6286):658-60.

22. Thallinger C., Fureder T., Preusser M. et al. Review of cancer treatment with immune checkpoint inhibitors: Current concepts, expectations, limitations and pitfalls. Wien Klin Wochenschr 2018;130(3-4):85-91. DOI: 10.1007/ s00508-017-1285-9.
23. Bahleda R., Braiteh F.S., Balmanoukian A.S. et al. Long-term safety and clinical outcomes of atezolizumab in head and neck cancer: phase la trial results. Ann Oncol 2017;28(5):v372-94. DOI: 0.1093/ annonc/mdx374.001a.

24. Zandberg D., Algazi A., Jimeno A. et al. Durvalumab for recurrent/metastatic $(\mathrm{R} / \mathrm{M})$ head and neck squamous cell carcinoma (HNSCC): Preliminary results from a single-arm, phase 2 study. Ann Oncol 2017;28(5):v372-94. DOI: 0.1093/ annonc/mdx374.

25. Scheel A.H., Dietel M., Heukamp L.C. et al. Harmonized PD-L1 immunohistochemistry for pulmonary squamous-cell and adenocarcinomas. Mod Pathol 2016;29(10):1165-72. DOI: 10.1038/ modpathol.2016.117.

26. Hirsch F.R., McElhinny A., Stanforth D. et al. PD-L1 immunohistochemistry assays for lung cancer: results from phase 1 of the Blueprint PD-L1 IHC Assay Comparison Project. J Thorac Oncol 2017;12(2):20822. DOI: $10.1016 /$ j.jtho.2016.11.2228.

27. Ferris R.L., Clump D.A., Ohr J. et al. Phase I trial of cetuximab, intensity modulated radiotherapy (IMRT), and ipilimumab in previously untreated, locally advanced head and neck squamous cell carcinoma (PULA HNSCC). Ann Oncol 2017;28(Suppl 5). DOI: 10.1093/annonc/ $\mathrm{mdx} 374.014$

28. BMS. Study of Nivolumab in Combination With Ipilimumab Compared to the Standard of Care (Extreme Study Regimen) as First Line Treatment in Patients With Recurrent or Metastatic Squamous Cell Carcinoma of the Head and Neck (CheckMate 651). 2016. Available at: https://clinicaltrials.gov/ct2/show/ NCT02741570.

29. BMS. Study of Nivolumab in Combination With Ipilimumab Versus Nivolumab in Combination With Ipilimumab Placebo in Patients With Recurrent or Metastatic Squamous Cell Carcinoma of the Head and Neck (CheckMate 714). 2018. Available at: https://clinicaltrials.gov/ct2/show/ NCT02823574.

30. NN. AstraZeneca Head and Neck Trials. 27.10.2016. Available at: https:// www.astrazeneca.com/media-centre/ press-releases/2016/astrazeneca-headand-neck-cancer-trials-27102016.html

31. MSD. Pembrolizumab in Combination With Cisplatin and Intensity Modulated Radiotherapy (IMRT) in Head and Neck Cancer. 2016. Available at: https://clinicaltrials.gov/ct2/show/NCT02777385.

32. BMS. An Investigational Immuno-therapy Trial of Nivolumab, or Nivolumab Plus Ipilimumab, or Nivolumab Plus Platinumdoublet Chemotherapy, Compared to Platinum Doublet Chemotherapy in Patients With Stage IV Non-Small Cell Lung Cancer (NSCLC) (CheckMate 227). 2015. Available at: https://clinicaltrials.gov/ct2/ show/NCT02477826.

33. BMS. Oropharyngeal Tumor Induction Chemotherapy and Response-stratified Locoregional Therapy Trial in Order to Minimize Long-term Adverse Events (OPTIMA II). 2017. Available at: https:// clinicaltrials.gov/ct2/show/NCT03107182.

34. Kintsler S. et al. PD-L1 Immunohistochemical stains and comparison of 10 available antibodies and their staining behaviour and costs. Mod Pathol, under Review 2018.

\section{Authors' contributions}

A. Mudunov: developing the research design;

A. Ahundov: article writing, reviewing of publications of the article's theme; obtaining data for analysis; analysis of the obtained data;

M. Bolotin: article writing, reviewing of publications of the article's theme; obtaining data for analysis; analysis of the obtained data;

T. Braunschweig: developing the research design, article writing, reviewing of publications of the article's theme; obtaining data for analysis; analysis of the obtained data.

Вклад авторов

А. Мудунов: разработка дизайна исследования;

А. Ахундов: написание текста статьи, обзор публикаций по теме статьи, получение данных для анализа, анализ полученных данных;

М. Болотин: написание текста статьи, обзор публикаций по теме статьи, получение данных для анализа, анализ полученных данных;

Т. Брауншвейг: разработка дизайна исследования, написание текста статьи, обзор публикаций по теме статьи, получение данных для анализа, анализ полученных данных.

\section{ORCID of authors}

A. Mudunov: https://orcid.org/0000-0002-0918-3857

A. Ahundov: https://orcid.org/0000-0002-9543-990X

T. Braunschweig: https://orcid.org/0000-0002-7760-5556 


\section{ORCID авторов}

А. Мудунов: https://orcid.org/0000-0002-0918-3857

А. Ахундов: https://orcid.org/0000-0002-9543-990Х

Т. Брауншвейг: https://orcid.org/0000-0002-7760-5556

Conflict of interest. T. Braunschweig: no conflict of interest; invited speaker: MSD, BMS, Roche, Boehringer-Ingelheim; invited Advisory board member: BMS. Other authors declare no conflict of interest.

Конфликт интересов. Т. Брауншвейг: отсутствует конфликт интересов; приглашенный докладчик: MSD, BMS, Roche, Boehringer-Ingelheim; приглашенный член консультативного совета: ВMS. Остальные авторы заявляют об отсутствии конфликта интересов.

Financing. The study was performed without external funding.

Финансирование. Исследование проведено без спонсорской поддержки. 